\title{
Short-Term Results of Patients Undergoing Arthroscopic Subacromial Decompression and Acromioplasty
}

\author{
Tacettin AYANOGLU 國, Yasin Emre KAYA [ ${ }^{1}$
}

\begin{abstract}
Aim: The aim of this study is to evaluate the arthroscopic surgery results of cases with isolated subacromial impingement syndrome (SIS) that do not respond to conservative treatment.

Material and Methods: 44 patients who had arthroscopic subacromial decompression and acromiplasty due to SIS between 2015 and 2018, were retrospectively analyzed. Patients with isolated subacromial impingement syndrome who did not respond to conservative treatment including drugs, physiotherapy, exercises and subacromial steroid injections were included. For the patients, preoperative and postoperative The American Shoulder and Elbow Surgeons Shoulder (ASES) Scores were measured.

Results: Forty-four patients with a mean follow-up of 26.4 months (ranging from 24 to 35 months; SD: 7.3) and a mean age of 51.4 (ranging from 39 to 55; SD: 6.96) were reached. Thirty (68\%) of the patients were female and fourteen (32\%) were male. There were no significant differences between groups according to the age, sex, and follow-up time $(\mathrm{p}>0.50)$. There were type 3 acromion in total of 7 patients and type 2 acromion in 18 patients. The overall mean preperative ASES score was 38.8 (ranging from 36.6 to 41.8). And, the mean postoperaive ASES score was 84.9 (ranging from 76.2 to 88.3 ).

Conclusion: The short-term clinical results of subacromial decompression and acromioplasty in patients who do not respond to conservative treatment has successfull results that support literature knowledge.
\end{abstract}

Keywords: Shoulder pain; shoulder impingement syndrome; arthroscopy; operative therapy.

\section{Artroskopik Subakromiyal Dekompresyon ve Akromiyoplasti Uygulanan Hastaların Kısa Dönem Sonuçları}

\section{Öz}

Amaç: Bu çalışmanın amacı, konservatif tedaviye yanıt vermeyen izole subakromiyal sıkışma sendromu (SSS) olan vakaların artroskopik cerrahi sonuçlarını değerlendirmektir.

Gereç ve Yöntemler: 2016-2018 yılları arasında SSS'e bağlı artroskopik subakromiyal dekompresyon ve akromiplasti olan ve düzenli takiplere gelen 44 hasta retrospektif olarak incelendi. NSIAD'ler, fizyoterapi, egzersizler ve subakromiyal steroid enjeksiyonları dahil konservatif tedaviye yanıt vermeyen izole subakromiyal sıkışma sendromlu hastalar dahil edildi. Hastaların ameliyat öncesi ve sonrası Amerikan Omuz ve Dirsek Cerrahları Omuz (ASES) Skorları ölçüldü.

Bulgular: Ortalama takip süresi 2,4 ay (24-35 ay arasında değişen; SS: 7,3) ve yaş ortalaması 51,4 (39-55; SS: 6,96) olan kırk dört hastaya ulaşıldı. Hastaların 30'u (\% 68) kadın, 14'ü (\% 32) erkekti. Gruplar arasında yaşa, cinsiyete ve takip süresine göre anlamlı fark yoktu ( $\mathrm{p}>0,50)$. Toplam 7 hastada tip 3 akromiyon, 18 hastada tip 2 akromiyon vardı. Genel ortalama hazırlayıcı ASES skoru 38,8 idi (36,6 ile 41,8 arasında). Ortalama postoperatif ASES skoru 84,9 idi (76,2 ile 88,3 arasinda).

Sonuç: Konservatif tedaviye yanıt vermeyen hastalarda subakromiyal dekompresyon ve akromioplastinin kısa dönem klinik sonuçları literatür bilgisini destekleyen başarılı sonuçlara sahiptir.

Anahtar Kelimeler: Omuz ağrısı; omuz sıkışma sendromu; artroskopi; cerrahi tedavi.

1 Department of Orthopedic and Traumatology, Medical Faculty of Bolu Abant Izzet Baysal University, Bolu, Turkey 


\section{INTRODUCTION}

Pain typically occurs with compression of the subacromial and subdeltoid bursa, rotator cuff tendons, or the long head of the biceps between the coracoacromial arch and the humeral head when raising the arm (1). Neer first defined the SIS and divided it into three phases. Neer described chronic bursitis in the initial stage, partial or full-thickness supraspinatus tendon ruptures in the advanced stage, tears of the remaining part of the rotator cuff and the addition of long biceps tendon problems in the last stage (2). The relationship between SIS and rotator cuff injury is not clear. Some authors say that it causes the development of rotator cuff damage due to external pressure $(3,4)$. It has been reported that osteophytes in the anterior and medial of the acromion are the main pathology (2). These changes revealed that the rotator cuff and the humeral head were primarily in the anterior rather than laterally due to compression between the anterior of the acromion and the coracoacromial ligament. In addition, it has been revealed that the anatomical shape of the acromion is also important on SIS development. In particular, the Type 3 acromion has also been shown to be closely related to rotator cuff tears (5).

It is possible to diagnose and manage the treatment of the SIS with the history, physical examination and appropriate imaging in addition to these. Typically the pain is seen at $70^{\circ}-120^{\circ}$ abduction. Neer and Hawkins tests are the most commonly used tests for the diagnosis of impingement (6). Although these tests are very sensitive, their specificity are not very high. There are also strong meta-analysis results suggesting that the liftoff test is more sensitive in diagnosis of SIS (7). Radiographs must be taken to evaluate the coracoacromial arch. However, Magnetic Resonans Imaging (MRI) provides a detailed assessment of possible impingement areas. The narrowest point in sagittal and coronal images is less than $7 \mathrm{~mm}$ supports the subacromial impingement syndrome (8).

Conservative treatment of SIS includes rest, lifestyle changes, injections, strengthening the muscles, ultrasound (US) and physical therapy modalities (9). Surgical treatment is generally preferred in cases where conservative treatment fails (10). With the advances in arthroscopy, arthroscopic subacromial decompression has become the gold standard treatment method in SIS treatment. Many studies have found that arthroscopic treatment gives better results than open surgery (11).

The aim of this study is to evaluate the arthroscopic surgery results of cases with isolated subacromial impingement syndrome that do not respond to conservative treatment.

\section{MATERIAL AND METHODS}

After the approval of Bolu Abant Izzet Baysal University University Clinical Researches Ethics Committee (2021/19), 44 patients who had arthroscopic subacromial decompression and acromiplasty due to SIS between 2015 and 2018, were retrospectively analyzed. The written consent was obtained from the patients and they were asked to fill in the informed consent form.

Patients with isolated subacromial impingement syndrome who did not respond to conservative treatment including anti-inflammatory drugs, physiotherapy, exercises and injections were included. Patients with supraspinatus tear, subscapularis tear, infraspinatus tear, adhesive capsulitis, previous fractures or a history of surgery were excluded from the study. Video records consisting of the described surgery were used to evaluate the presence of a cuff tear, degree of CAL degeneration, and associated pathologic change for each patient.

Patients with complaints of pain and limitation of movement were evaluated with physical examination and magnetic resonance imaging techniques and their first treatment was initiated. First of all, it was decided to perform arthroscopic evaluation for the patients who received conservative treatment and whose treatment failed. Patients' preoperative and postoperative shoulderjoint motions were measured both actively and passively. For the patients, preoperative and postoperative ASES (The American Shoulder and Elbow Surgeons) Shoulder Scores were measured.

\section{Surgical technique}

All patients were operated arthroscopically under the interscalene block in the lateral decubitus position. First, standard glenohumeral joint examination was performed, the presence of intraarticular pathology such as biceps long head pathologies, slap lesion, rotator cuff, labrum was evaluated. After glenohumeral arthroscopy, subacromial arthroscopy was performed to examine the bursal-side rotator cuff disease, CAL, acromion, and bursa. CAL degeneration, which is an arthroscopic indicator of subacromial impingement syndrome, was evaluated and staged according to Royal Berkshire Hospital classification. Subacromial decompression and acromiplasty were performed in patients with stage 2-3 CAL degeneration (Figure 1 and 2).

\section{Statistical Analysis}

Statistical analyses of demographic data and the presence of subacromial impingement syndrome were made using SPSS/PC (version 18.0 for Windows; SPSS Inc, Chicago, IL, USA). The normality of distribution of the continuous variables was tested with the Kolmogorov-Smirnov test. Wilcoxon's signed-rank test was used for comparisons of the preoperative and post-operative ASES. $\mathrm{p}$ value of $<0.05$ was considered statistically significant.

\section{RESULTS}

Forty-four patients with a mean follow-up of 26.4 months (ranging from 24 to 35 months; SD: 7.3) and a mean age of 51.4 (ranging from 39 to 55; SD: 6.96) were reached. Thirty $(68 \%)$ of the patients were female and fourteen (32\%) were male. There were no significant differences between groups according to the age, sex, and follow-up time $(p>0.50)$. There was type 3 acromion in total of 7 patients and type 2 acromion in 18 patients.

The overall mean preperative ASES score was 38.8 (ranging from 36.6 to 41.8 ). And, the mean postoperaive ASES score was 84.9 (ranging from 76.2 to 88.3 (Tablo 1). There was no statistically significant difference in preoperative and postoperative clinical scores according to gender and acromion type (Table 2). 
Table 1. Demographic characteristics and shoulder scores of all patients

\begin{tabular}{|l|l|l|l|l|l|c|c|}
\hline $\begin{array}{l}\text { Male/Female } \\
\text { (ratio) }\end{array}$ & $\begin{array}{l}\text { Age } \\
\text { (mean,year) }\end{array}$ & $\begin{array}{l}\text { Folow-up } \\
\text { (mean,month) }\end{array}$ & $\begin{array}{l}\text { ASES score } \\
\text { preoperative, } \\
\text { mean }\end{array}$ & $\begin{array}{l}\text { ASES score } \\
\text { postoperative, } \\
\text { mean }\end{array}$ & $\begin{array}{l}\text { Type 1 } \\
\text { acromion }\end{array}$ & $\begin{array}{l}\text { Type } \\
\text { acromion }\end{array}$ & $\begin{array}{l}\text { Type } \\
\text { acromion }\end{array}$ \\
\hline $32 / 68 \%$ & 51.4 & 26.4 & 38.8 & 84.9 & 19 & 18 & 7 \\
\hline
\end{tabular}

Table 2. The effect of gender and acromion type on clinic scores.

\begin{tabular}{|l|c|c|c|c|}
\hline & & $\begin{array}{c}\text { ASES } \\
\text { preoperative }\end{array}$ & $\begin{array}{c}\text { ASES } \\
\text { postoperative }\end{array}$ & P \\
\hline Gender & Male & 40.50 & 85.40 & 0.706 \\
\cline { 2 - 4 } & Female & 37.09 & 84.29 & \\
\hline $\begin{array}{l}\text { Acromion } \\
\text { type }\end{array}$ & Type 1 & 38.0 & 87.65 & \multirow{2}{*}{0.447} \\
\cline { 2 - 4 } & Type 2 & 35.50 & 84.00 & \\
\cline { 2 - 4 } & Type 3 & 34.01 & 83.49 & \\
\hline \multicolumn{2}{|l|}{} & & & \\
ASES score: The American Shoulder and Elbow Surgeons Shoulder Scores
\end{tabular}

\section{DISCUSSION}

Neer explained this syndrome as mechanical compression of the rotator cuff tendons under the antero-inferior part of the acromion and in the anterior flexion and internal rotation position of the shoulder (12). Many mechanisms have been suggested in the formation of this pathology. These can be examined in two main groups as internal (caused by pathologies within the tendon) and external (caused by pathologies in the tissues surrounding the tendon) causes (13). External causes include the presence of Type 3 acromion morphology, presence of os acromiale, acromioclavicular joint pathologies and instabilities $(12,14)$. It was emphasized that the compression was in the lateral of the acromion in the early days. However, over time, anterior acromioplasty has come to prominent. Pain at night and triggering pain during overhead activities are the most common findings. However, these findings can easily be confused with other shoulder pathologies. The differential diagnosis is made with Neer compression test, which is evaluated by the regression of the symptoms after local anesthetic injection $(12,15)$.

Treatment for impingement syndrome is divided into conservative and surgical. Conservative treatment options that are more frequently preferred are rest, lifestyle changes, injections, strengthening the muscles around the scapula, US and physical therapy modalities. The first treatment of patients should be physiotherapy. While there is no significant difference between the results of patients who undergo physiotherapy and surgery, it is reported that patients should undergo absolute physiotherapy before surgical treatment and surgery should be performed with the correct indication $(16,17)$. In a prospective study, corticosteroid injection and physical therapy were administered to 100 patients with SIS, and $79 \%$ of the patients did not require surgery during the two-year follow-up. The ASES scores of these patients increased from 56 to 95 (18). In another study, exercise was found to have a positive effect on pain and function, but no effect on range of motion and strength (19).

Surgical treatment is recommended for patients who do not respond to conservative treatment for 3--6 months. Surgical treatment is more successful especially in patients who do not have limitation of movement in the shoulder, who have a positive Neer and Hawkins test, who have reduced pain after lidocaine injection, who have Type 3 acromion and who have changes in the rotator cuff in MRI (20). Long-term successful results of open anterior acromioplasty have been reported (20). With the advances in arthroscopy, arthroscopic subacromial decompression has become the gold standard treatment method in SIS treatment. Many studies have found that arthroscopic treatment gives better results than open surgery $(20,21,22)$. Arthroscopic therapy includes subacromial decompression, bursectomy, coracoacromial ligament release, acromioplasty, os acromiale and assessment of the acromioclavicular joint. Subacromial bursa is located on the anterior potion of acromion. Subacromial decompression and bursectomy are standard surgical procedures for good imaging. Coracoacromial ligament degeneration classification is used for arthroscopic staging of subacromial impingement syndrome. The Royal Berkshire Hospital classification is frequently used $(4,23)$. If there is advanced stage degeneration, acromioplasty treatment is addedto surgical procedure (4).

The development of the technique makes arthroscopic acromioplasty prominent as a treatment option. In prospective studies, good clinical results have been reported in patients who underwent bursectomy only and those who underwent bursectomy and acromioplasty (24,25). Arthroscopic subacromial decompression provides short-term pain reduction and functional recovery (26). The results of this study also support the information in the literature. We observed that the application of subacromial decompression and acromioplasty increased from 38 to 84 in ASES scores in the short term.

There are several limitations of the current study. Firstly, despite the prospective collection of data, this study has a retrospective nature. Secondly, the low number of patients is also a deficiency. Thirdly, the absence of a control group is another limitation. However, the strengths of the study are that all patients had isolated impingement syndrome and all were operated by a single surgeon.

There is a consensus that the first treatment of isolated subacromial impingement should be conservative. We report good short-term clinical results of subacromial decompression and acromioplasty in patients who do not respond to conservative treatment. 
Authors's Contributions: Idea/Concept: T.A.; Design: T.A.; Data Collection and/or Processing: Y.E.K.; Analysis and/or Interpretation: Y.E.K.; Literature Review: T.A.; Writing the Article: T.A.; Critical Review: Y.E.K.

\section{REFERENCES}

1. Roddy E, Zwierska I, Hay EM, Jowett S, Lewis M, Stevenson K, et al. SUPPORT trial team. Subacromial impingement syndrome and pain: protocol for a randomised controlled trial of exercise and corticosteroid injection (the SUPPORT trial). BMC Musculoskelet Disord. 2014; 15(1): 81.

2. Neer CS 2nd. Anterior acromioplasty for the chronic impingement syndrome in the shoulder: a preliminary report. J Bone Joint Surg Am. 1972; 54(1): 41-50.

3. Bigliani LU, Levine WN. Subacromial impingement syndrome. J Bone Joint Surg Am 1997; 79(12): 185468.

4. Kanatli U, Ayanoğlu T, Aktaş E, Ataoğlu MB, Özer M, Çetinkaya M. Grade of coracoacromial ligament degeneration as a predictive factor for impingement syndrome and type of partial rotator cuff tear. J Shoulder Elbow Surg. 2016; 25(11): 1824-8.

5. Bigliani BU, Morrison ES, April EW. The morphology of the acromion and its relationship to rotator cuff tears. Orthop Trans. 1986; 10: 216.

6. Pappas GP, Blemker SS, Beaulieu CF, McAdams TR, Whalen ST, Gold GE. In vivo anatomy of the Neer and Hawkins sign positions for shoulder impingement. J Shoulder Elbow Surg. 2006; 15(1): 40-9.

7. Marwan A, Galvin. Diagnostic accuracy of clinical tests for subacromial impingement syndrome: a systematic review and meta-analysis. Arch Phys Med Rehabil. 2012; 93: 229-36.

8. Roberts CS, Davila JN, Hushek SG, Tillett ED, Corrigan TM. Magnetic resonance imaging analysis of the subacromial space in the impingement sign positions. J Shoulder Elbow Surg. 2002; 11(6): 595-9.

9. Liaghat B, Ussing A, Petersen BH, Andersen HK, Barfod KW, Jensen MB, et al. Supervised training compared with no training or self-training in patients with subacromial pain syndrome: a systematic review and meta-analysis. Arch Phys Med Rehabil. 2021; 27: S0003-9993(21)00318-X.

10. Haahr JP, Ostergaard S, Dalsgaard J, Norup K, Frost $\mathrm{P}$, Lausen $\mathrm{S}$, et al. Exercises versus arthroscopic decompression in patients with subacromial impingement: a randomised, controlled study in 90 cases with a one year follow up. Ann Rheum Dis. 2005; 64(5): 760-4.

11. Davis AD, Kakar S, Moros C, Kaye EK, Schepsis AA, Voloshin I: Arthroscopic versus open acromioplasty: A metaanalysis. Am J Sports Med. 2010; 38(3): 613-8.

12. Hardy V, Rony L, Bachler J, Favard L, Hubert L. Does anterior arthroscopic acromioplasty modify critical shoulder angle? Orthop Traumatol Surg Res. 2021; 16: 102936.

13. Michener LA, McClure PW, Karduna AR. Anatomical and biomechanical mechanisms of subacromial impingement syndrome. Clin Biomech (Bristol, Avon) 2003; 18(5): 369-79.

14. Ma Q, Sun C, Du R, Liu P, Wu S, Zhang W, et al. Morphological characteristics of acromion and acromioclavicular joint in patients with shoulder 1mpingement syndrome and related recommendations: A three-dimensional analysis based on multiplanar reconstruction of computed tomography scans. Orthop Surg. 2021; 13(4): 1309-18. https://doi.org/ 10.1111/os.13001.

15. Zadro JR, O'Keeffe M, Ferreira GE, Haas R, Harris IA, Buchbinder R, et al. Diagnostic Labels for Rotator Cuff Disease Can Increase People's Perceived Need for Shoulder Surgery: An Online Randomized Controlled Experiment. J Orthop Sports Phys Ther. 2021; 51(8): 401-11.

16. Christiansen DH, Hjort J. Group-based exercise, individually supervised exercise and home-based exercise have similar clinical effects and costeffectiveness in people with subacromial pain: a randomised trial. J Physiother. 2021; 67(2): 124-31.

17. Kim YB, Lee WS, Won JS. The effects of a singledose subacromial injection of a nonsteroidal antiinflammatory drug in geriatric patients with subacromial impingement syndrome: a randomized double-blind study. Clin Shoulder Elb. 2021; 24(1): 48 .

18. Cummins CA, Sasso LM, Nicholson D. Impingement syndrome: Temporal outcomes of nonoperative treatment. J Shoulder Elbow Surg 2009; 18(2): 172-7.

19. Kuhn JE. Exercise in the treatment of rotator cuff impingement: A systematic review and a synthesized evidence-based rehabilitation protocol. J Shoulder Elbow Surg. 2009; 18(1): 138-60.

20. Waterman BR, Newgren J, Gowd AK, Cabarcas B, Lansdown D, Bach BR, et al. Randomized Prospective Trial of Arthroscopic Rotator Cuff with or without Acromioplasty: No Difference in PatientReported Outcomes at Long-Term Follow-up. Arthroscopy. 2021; 30: S0749-8063(21)00404-7. https://doi.org/10.1016/j.arthro.2021.04.041

21. Davis AD, Kakar S, Moros C, Kaye EK, Schepsis AA, Voloshin I: Arthroscopic versus open acromioplasty: A metaanalysis. Am J Sports Med. 2010; 38(3): 613-8.

22. Kappe T, Knappe K, Elsharkawi M, Reichel H, Cakir B. Predictive value of preoperative clinical examination for subacromial decompression in impingement syndrome. Knee Surg Sports Traumatol Arthrosc. 2015; 23(2): 443-8.

23. Medancic N, Spanic M, Marinic TB, Klobucar H, Cicak N. Arthroscopic removal of arch-shaped rotator cuff calcifying tendinitis without rotator cuff repair and acromioplasty is an excellent treatment regarding pain relief and function. Int Orthop. 2021; 45(4): 1003-7. https://doi.org/10.1007/s00264-020-04930-1

24. Henkus HE, de Witte PB, Nelissen RG, Brand R, van Arkel ER. Bursectomy compared with acromioplasty in the management of subacromial impingement syndrome: a prospective randomised study. J Bone Joint Surg Br. 2009; 91(4): 504-10.

25. Kolk A, Thomassen BJW, Hund H, de Witte PB, Henkus HE, Wassenaar WG, et al. Does 
acromioplasty result in favorable clinical and radiologic outcomes in the management of chronic subacromial pain syndrome? A double-blinded randomized clinical trial with 9 to 14 years' follow-up. J Shoulder Elbow Surg. 2017; 26(8): 1407-15.

26. Kukkonen J, Ryösa A, Joukainen A, Lehtinen J, Kauko T, Mattila K, et al. Operative vs. conservative treatment of small non-traumatic supraspinatus tears in patients over 55 years: Over 5-year follow-up of a randomized contralled trial. J Shoulder Elbow Surg. 2021; 24: S1058-2746(21)00330-X. https://doi.org/ $10.1016 /$ j.jse.2021.03.133. 